ACTA AGROBOTANICA

Vol. 62 (1): 155-162

2009

\title{
THE EFFECT OF FOLIAR FEEDING OF POTASSIUM SALTS AND UREA IN SPINACH ON GAS EXCHANGE, LEAF YIELD AND QUALITY
}

\author{
Edward Borowski, Sławomir Michałek
}

\author{
Department of Plant Physiology, University of Life Sciences in Lublin, \\ Akademicka 15, 20-950 Lublin. Poland, e-mail: slawomir.michalek@up.lublin.pl
}

Received: 3.03.2009

\section{Abstract}

In a pot experiment conducted in a phytotron, the effectiveness of foliar feeding of different potassium salts, with and without the addition of $0.5 \% \mathrm{CO}\left(\mathrm{NH}_{2}\right)_{2}$, in spinach (Spinacia oleracea $\mathrm{L}$.) was investigated. Potassium was applied 3 times in the form of $1 \%$ solutions $\mathrm{KCl}, \mathrm{KNO}_{3}, \mathrm{~K}_{2} \mathrm{SO}_{4}$ and $\mathrm{C}_{6} \mathrm{H}_{5} \mathrm{~K}_{3} \mathrm{O}_{7} \cdot \mathrm{H}_{2} \mathrm{O}$, compared to water as the control treatment. The obtained results show that foliar feeding of potassium salts in spinach is an efficient method of supplementing the level of $\mathrm{K}^{+}$in plants during vegetation. Plants fed with $\mathrm{KNO}_{3}$ had the highest content of potassium in leaves, and those fertilized with $\mathrm{K}_{2} \mathrm{SO}_{4}, \mathrm{C}_{6} \mathrm{H}_{5} \mathrm{~K}_{3} \mathrm{O}_{7}$ $\times \mathrm{H}_{2} \mathrm{O}$ and $\mathrm{KCl}$ had an only slightly lower potassium content. The application of potassium salts resulted in more intensive gas exchange in leaves (stomatal conductance, photosynthesis, transpiration) and, as a consequence of that, increased leaf yield. Potassium nitrate and citrate influenced most effectively the abovementioned processes. The treatment of spinach with potassium salts resulted in an increased content of protein, chlorophyll, carotenoids, nitrates and iron as well as a decreased content of vitamin $\mathrm{C}$ and calcium in leaves.

Key words: Spinacia oleracea, potassium salts, urea, foliar feeding, gas exchange, yield, leaf quality.

\section{INTRODUCTION}

The yielding of spinach (Spinacia oleracea L.) depends primarily on water and nutrient availability in soil (Orłowski and Kołota, 1999). Potassium is the main ion of osmotic solution in plants (M e n ge 1 and Arneke, 1982). Its accumulation in cells leads to osmotic water uptake and generates cell turgor necessary for growth (M e n gel and Arneke, 1982; De La Guardia and Benlloch, 1980) and pore opening ( $\mathrm{Fisher}$ and $\mathrm{Hs}$ i a o, 1968). In whole plants, the level of $\mathrm{K}^{+}$affects the osmotic absorption of water by roots, controls leaf transpiration (H s i a o and Lä u c h li, 1986) and increases vitamin
$\mathrm{C}$ content in fruits ( $\mathrm{H} \mathrm{u}$ a $\mathrm{ng}$ et al. 2000). Its relatively large concentration is a condition necessary for protein biosynthesis (M a r c h n e r, 1995).

The versatile role of potassium ions in plants arises from the fact that potassium is an activator or coenzyme of numerous plant enzymes (B u s s a k o r n et al. 2003). The only way to quickly supplement any potassium deficiencies during cultivation is to apply foliar feeding of this element. In Poland there are no studies on the effect of foliar feeding of potassium on yield and its quality as well as on the effectiveness of different forms of potassium salts. But data available in foreign literature show that potassium, as the monovalent cation with a relatively small diameter, easily passes through the leaf epidermis (M e n g e 1, 2002). When applying different foliar fertilisers in spinach cultivation, A lan and Padem (1994) found its highest content in leaves already after 24-48 hours after application.

The penetration of the potassium cation into plant leaves, as shown in literature, depends on the applied form of potassium salt, however, results in this respect are not unambiguous. W i t $t \mathrm{w}$ e $\mathrm{r}$ and $\mathrm{T}$ e $\mathrm{u}$ b n e r (1959) showed the highest uptake of foliar-applied $\mathrm{K}$ ions from potassium citrate solution, whereas A b a di a et al. (2002) and R e ed et al. (1988) claim that the application of chelated forms of this nutrient do not increase its absorption compared to inorganic salt forms, and it only increases its mobility in the plant. Also, there is a lack of agreement between researchers with regard to the effectiveness of inorganic potassium salts. R e s tre p o D i a z et al. (2008), applying foliar fertilization of olive trees with $\mathrm{KCl}$ and $\mathrm{K}_{2} \mathrm{SO}_{4}$ solutions, did not find any differences in growth, fruiting and $\mathrm{K}$ content in fruits, whereas $\mathrm{U} \mathrm{m}$ a r et al. (1999), applying the same salts in peanut plants, showed that $\mathrm{KCl}$ had a more beneficial effect on yield, whereas $\mathrm{K}_{2} \mathrm{SO}_{4}$ on protein and fat content in seeds. Mile $\mathrm{y}$ 
and Oosterhuis (1994), applying foliar feeding of $\mathrm{KNO}_{3}, \mathrm{~K}_{2} \mathrm{SO}_{4}, \mathrm{KCl}$ and $\mathrm{K}_{2} \mathrm{CO}_{3}$ solutions in cotton plants, found that $\mathrm{KNO}_{3}$ had significantly increased the yield of seed hairs and bolls compared to the control treatment and $\mathrm{K}_{2} \mathrm{CO}_{3}$. There are no studies on the effect of foliar-applied potassium salt forms on the growth and yield quality of leaf vegetables as well as on the interaction of these forms with urea. But the addition of urea during foliar application of macro- and micronutrients is used in horticultural practice, since it is generally thought that it increases the availability of other nutrients in leaves, which is also confirmed in a study by Kannan (1980) and We in ba m (1988).

In the light of the lack of studies on the effectiveness of foliar nutrition of leaf vegetables with potassium salts and the unknown usefulness of potassium salt forms available on the market, it seemed expedient to undertake such research.

\section{MATERIALS AND METHODS}

The experiments were conducted in a phytotron of the University of Life Sciences in 2008 in the period 12 May - 24 June (replication I) and 7 July - 18 August (replication II). Spinach plants (cv. 'Matador') grew in $1.5 \mathrm{dm}^{3}$ pots filled with medium for sowing and pricking out of leaf vegetables. One litre of growing medium contained 130mg N-NO $, 66 \mathrm{mg} \mathrm{P}, 165 \mathrm{mg} \mathrm{K}, 915 \mathrm{mg} \mathrm{Ca}$ and $141 \mathrm{mg} \mathrm{Mg}$, its $\mathrm{pH}$ in $\mathrm{H}_{2} \mathrm{O}$ was 5.5, whereas salinity $1.02 \mathrm{~g} \mathrm{NaCl} \times \mathrm{dm}^{-3}$. The experiment was carried out with fluorescent light, with far flux density of approx. $200 \mu$ moli $\times \mathrm{m}^{-2} \times \mathrm{s}^{-1}$, day length of 14 hours and temperature $18 / 15^{\circ} \mathrm{C}$ (day/night). Each experiment comprised 50 pots, with 2 plants growing in one pot. In the third week of growth, 10 experimental series were set up (5 pots in each), differentiated in terms of foliar-applied potassium salts and the addition of urea or not. The respective experimental series were sprayed with $1 \%$ water solutions of the following potassium salts: 1) $\mathrm{H}_{2} \mathrm{O}$ - control, 2) $\left.\mathrm{KCl}, 3\right) \mathrm{KNO}_{3}$, 4) $\mathrm{K}_{2} \mathrm{SO}_{4}$, 5) $\mathrm{C}_{6} \mathrm{H}_{5} \mathrm{~K}_{3} \mathrm{O}_{7} \cdot \mathrm{H}_{2} \mathrm{O}$ in pure form, or a mixture of particular salts with $0.5 \% \mathrm{CO}\left(\mathrm{NH}_{2}\right)_{2}$ (experiment design - Tab. 1). Foliar feeding of the abovementioned potassium salts in the plants was repeated in the fourth and fifth weeks of growth. The solutions were applied at air temperature of $18^{\circ} \mathrm{C}$, just before nightfall, using a manual sprayer, each time until full moisturizing of the accessible leaf surface was obtained.

After 5 days from the last spraying, measurements were made of leaf stomatal conductance for water vapour as well as transpiration and photosynthesis intensity. The measurements were made in 10 replications on fully-developed middle leaves of spinach rosettes, using a leaf microclimate control system LCA4. During recording, temperature in the measurement chamber was approx. $20^{\circ} \mathrm{C}$ and far flux density approx. $200 \mu$ moli $\times \mathrm{m}^{-2} \times \mathrm{s}^{-1}$.

Table 1

Effect of potassium salts and addition of urea on stomatal conductance and intensity of transpiration of spinach leaves.

\begin{tabular}{|c|c|c|c|c|c|c|}
\hline \multirow{2}{*}{$\begin{array}{l}\text { Potassium } \\
\text { salts }\end{array}$} & \multicolumn{2}{|c|}{ Solution } & \multirow[b]{2}{*}{ Mean } & \multicolumn{2}{|c|}{ Solution } & \multirow[b]{2}{*}{ Mean } \\
\hline & $\begin{array}{c}\text { without } \\
\text { urea }\end{array}$ & $\begin{array}{l}\text { with } \\
\text { urea }\end{array}$ & & $\begin{array}{c}\text { without } \\
\text { urea }\end{array}$ & $\begin{array}{l}\text { with } \\
\text { urea }\end{array}$ & \\
\hline & \multicolumn{3}{|c|}{ conductance $\left(\mathrm{mol} \mathrm{H} / 2 \mathrm{O} \times \mathrm{m}^{-2} \cdot \mathrm{s}^{-1}\right)$} & \multicolumn{3}{|c|}{ transpiration $\left(\mathrm{mmol} \mathrm{H}_{2} \mathrm{O} \times \mathrm{m}^{-2} \cdot \mathrm{s}^{-1}\right)$} \\
\hline Control $\left(\mathrm{H}_{2} \mathrm{O}\right)$ & 0.21 & 0.30 & 0.25 & 2.50 & 2.74 & 2,62 \\
\hline $\mathrm{KCl}$ & 0.29 & 0.34 & 0.31 & 3.16 & 3.24 & 3,20 \\
\hline $\mathrm{KNO}_{3}$ & 0.45 & 0.47 & 0.46 & 4.62 & 4.80 & 4,71 \\
\hline $\mathrm{K}_{2} \mathrm{SO}_{4}$ & 0.34 & 0.36 & 0.35 & 2.75 & 3.15 & 2,95 \\
\hline 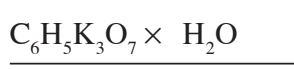 & 0.37 & 0.45 & 0.41 & 3.17 & 3.35 & 3,26 \\
\hline Mean & 0.33 & 0.38 & & 3.24 & 3.46 & \\
\hline $\mathrm{LSD}_{0.05}$ for salt & & 0.04 & & & 0.21 & \\
\hline $\mathrm{LSD}_{0.05}$ for urea & & 0.02 & & & 0.09 & \\
\hline $\mathrm{LSD}_{0.05}$ for salt $\times$ urea & & 0.07 & & & n.s. & \\
\hline
\end{tabular}


Table 2

Effect of potassium salts and addition of urea on intensity of photosynthesis and fresh yield of spinach leaves.

\begin{tabular}{|c|c|c|c|c|c|c|}
\hline \multirow{2}{*}{$\begin{array}{l}\text { Potassium } \\
\text { salts }\end{array}$} & \multicolumn{2}{|c|}{ Solution } & \multirow[b]{2}{*}{ Mean } & \multicolumn{2}{|c|}{ Solution } & \multirow[b]{2}{*}{ Mean } \\
\hline & $\begin{array}{c}\text { without } \\
\text { urea }\end{array}$ & $\begin{array}{l}\text { with } \\
\text { urea }\end{array}$ & & $\begin{array}{c}\text { without } \\
\text { urea }\end{array}$ & $\begin{array}{l}\text { with } \\
\text { urea }\end{array}$ & \\
\hline & \multicolumn{3}{|c|}{ photosynthesis $\left(\mu \mathrm{mol} \mathrm{CO} \mathrm{CO}_{2} \times \mathrm{m}^{-2} \times \mathrm{s}^{-1}\right)$} & \multicolumn{3}{|c|}{ leaf weight $\left(\mathrm{g} \times\right.$ plant $\left.^{-1}\right)$} \\
\hline Control $\left(\mathrm{H}_{2} \mathrm{O}\right)$ & 6.25 & 6.66 & 6.45 & 10.9 & 13.0 & 11,9 \\
\hline $\mathrm{KCl}$ & 6.96 & 7.56 & 7.26 & 13.8 & 15.0 & 14,4 \\
\hline $\mathrm{KNO}_{3}$ & 8.86 & 9.28 & 9.07 & 15.4 & 17.3 & 16,3 \\
\hline $\mathrm{K}_{2} \mathrm{SO}_{4}$ & 7.35 & 7.93 & 7.64 & 14.2 & 14.5 & 14,3 \\
\hline $\mathrm{C}_{6} \mathrm{H}_{5} \mathrm{~K}_{3} \mathrm{O}_{7} \times \mathrm{H}_{2} \mathrm{O}$ & 7.84 & 9.17 & 8.50 & 14.3 & 16.7 & 15,5 \\
\hline Mean & 7.45 & 8.12 & & 13.7 & 15.3 & \\
\hline $\mathrm{LSD}_{0.05}$ for salt & & 0.33 & & & 2.2 & \\
\hline $\mathrm{LSD}_{0.05}$ for urea & & 0.15 & & & 1.0 & \\
\hline $\mathrm{LSD}_{0.05}$ for salt $\times$ urea & & 0.54 & & & n.s. & \\
\hline
\end{tabular}

Table 3

Effect of potassium salts and addition of urea on content of crude protein and nitrates in fresh weight of spinach leaves.

\begin{tabular}{|c|c|c|c|c|c|c|}
\hline \multirow{2}{*}{$\begin{array}{l}\text { Potassium } \\
\text { salts }\end{array}$} & \multicolumn{2}{|c|}{ Solution } & \multirow[b]{2}{*}{ Mean } & \multicolumn{2}{|c|}{ Solution } & \multirow[b]{2}{*}{ Mean } \\
\hline & $\begin{array}{c}\text { without } \\
\text { urea }\end{array}$ & $\begin{array}{l}\text { with } \\
\text { urea }\end{array}$ & & $\begin{array}{c}\text { without } \\
\text { urea }\end{array}$ & $\begin{array}{l}\text { with } \\
\text { urea }\end{array}$ & \\
\hline & \multicolumn{3}{|c|}{ protein $\left(m g \times g^{-1}\right.$ f.m.) } & \multicolumn{3}{|c|}{ nitrates $\left(\mu \mathrm{gNO}_{3} \times \mathrm{g}^{-1}\right.$ f.m. $)$} \\
\hline Control $\left(\mathrm{H}_{2} \mathrm{O}\right)$ & 25.4 & 32.3 & 28.8 & 132.2 & 148.7 & 140,4 \\
\hline $\mathrm{KCl}$ & 29.6 & 35.0 & 32.3 & 152.8 & 221.9 & 187,3 \\
\hline $\mathrm{KNO}_{3}$ & 30.7 & 35.9 & 33.3 & 444.2 & 611.5 & 527,8 \\
\hline $\mathrm{K}_{2} \mathrm{SO}_{4}$ & 26.6 & 29.5 & 28.0 & 196.2 & 262.4 & 229,3 \\
\hline $\mathrm{C}_{6} \mathrm{H}_{5} \mathrm{~K}_{3} \mathrm{O}_{7} \times \mathrm{H}_{2} \mathrm{O}$ & 30.0 & 36.9 & 33.4 & 256.1 & 376.0 & 316,0 \\
\hline Mean & 28.5 & 33.9 & & 236.3 & 324.1 & \\
\hline $\mathrm{LSD}_{0.05}$ for salt & & 4.4 & & & 95.2 & \\
\hline $\mathrm{LSD}_{0.05}$ for urea & & 1.9 & & & 42.0 & \\
\hline $\mathrm{LSD}_{0.05}$ for salt $\times$ urea & & n.s. & & & n.s. & \\
\hline
\end{tabular}


Table 4

Effect of potassium salts and addition of urea on content of chlorophyll "a+b" and carotenoids in spinach leaves.

\begin{tabular}{|c|c|c|c|c|c|c|}
\hline \multirow{2}{*}{$\begin{array}{l}\text { Potassium } \\
\text { salts }\end{array}$} & \multicolumn{2}{|c|}{ Solution } & \multirow[b]{2}{*}{ Mean } & \multicolumn{2}{|c|}{ Solution } & \multirow[b]{2}{*}{ Mean } \\
\hline & $\begin{array}{c}\text { without } \\
\text { urea }\end{array}$ & $\begin{array}{l}\text { with } \\
\text { urea }\end{array}$ & & $\begin{array}{c}\text { without } \\
\text { urea }\end{array}$ & $\begin{array}{l}\text { with } \\
\text { urea }\end{array}$ & \\
\hline & \multicolumn{3}{|c|}{ chlorophyll (mg $\times \mathrm{g}^{-1}$ f.m.) } & \multicolumn{3}{|c|}{ carotenoids $\left(\mathrm{mg} \times \mathrm{g}^{-1}\right.$ f.m. $)$} \\
\hline Control $\left(\mathrm{H}_{2} \mathrm{O}\right)$ & 2.03 & 2.28 & 2.15 & 0.28 & 0.33 & 0,30 \\
\hline $\mathrm{KCl}$ & 2.37 & 2.59 & 2.48 & 0.32 & 0.35 & 0,33 \\
\hline $\mathrm{KNO}_{3}$ & 2.82 & 3.00 & 2.91 & 0.37 & 0.41 & 0,39 \\
\hline $\mathrm{K}_{2} \mathrm{SO}_{4}$ & 2.47 & 2.77 & 2.62 & 0.34 & 0.37 & 0,35 \\
\hline $\mathrm{C}_{6} \mathrm{H}_{5} \mathrm{~K}_{3} \mathrm{O}_{7} \times \mathrm{H}_{2} \mathrm{O}$ & 2.52 & 2.80 & 2.66 & 0.37 & 0.40 & 0,38 \\
\hline Mean & 2.44 & 2.69 & & 0.34 & 0.37 & \\
\hline $\mathrm{LSD}_{0.05}$ for salt & \multicolumn{3}{|c|}{0.34} & \multicolumn{3}{|c|}{0.05} \\
\hline $\mathrm{LSD}_{0.05}$ for urea & \multicolumn{3}{|c|}{0.15} & \multicolumn{3}{|c|}{0.02} \\
\hline $\mathrm{LSD}_{0.05}$ for salt $\times$ urea & \multicolumn{3}{|c|}{ n.s. } & \multicolumn{3}{|c|}{ n.s. } \\
\hline
\end{tabular}

Table 5

Effect of potassium salts and addition of urea on content of vitamin $\mathrm{C}$ and iron in spinach leaves.

\begin{tabular}{|c|c|c|c|c|c|c|}
\hline \multirow{2}{*}{$\begin{array}{l}\text { Potassium } \\
\text { salts }\end{array}$} & \multicolumn{2}{|c|}{ Solution } & \multirow[b]{2}{*}{ Mean } & \multicolumn{2}{|c|}{ Solution } & \multirow[b]{2}{*}{ Mean } \\
\hline & $\begin{array}{c}\text { without } \\
\text { urea }\end{array}$ & $\begin{array}{l}\text { with } \\
\text { urea }\end{array}$ & & $\begin{array}{c}\text { without } \\
\text { urea }\end{array}$ & $\begin{array}{l}\text { with } \\
\text { urea }\end{array}$ & \\
\hline & \multicolumn{3}{|c|}{ vitamin $\mathrm{C}\left(\mathrm{mg} \times 100 \mathrm{~g}^{-1} \mathrm{f} . \mathrm{m}.\right)$} & \multicolumn{3}{|c|}{ iron $\left(\mu \mathrm{g} \times \mathrm{g}^{-1} \mathrm{~d} . \mathrm{m}.\right)$} \\
\hline Control $\left(\mathrm{H}_{2} \mathrm{O}\right)$ & 90.3 & 103.3 & 96.8 & 90 & 100 & 95,0 \\
\hline $\mathrm{KCl}$ & 89.9 & 89.1 & 89.5 & 105 & 90 & 97,5 \\
\hline $\mathrm{KNO}_{3}$ & 87.8 & 94.5 & 91.2 & 115 & 110 & 112,5 \\
\hline $\mathrm{K}_{2} \mathrm{SO}_{4}$ & 79.1 & 93.3 & 86.2 & 90 & 100 & 95,0 \\
\hline $\mathrm{C}_{6} \mathrm{H}_{5} \mathrm{~K}_{3} \mathrm{O}_{7} \times \mathrm{H}_{2} \mathrm{O}$ & 89.0 & 88.9 & 88.9 & 115 & 120 & 117,5 \\
\hline Mean & 87.2 & 93.8 & & 103 & 104 & \\
\hline $\mathrm{LSD}_{0.05}$ for salt & & 3.4 & & & 13.1 & \\
\hline $\mathrm{LSD}_{0.05}$ for urea & & 1.5 & & & n.s. & \\
\hline $\mathrm{LSD}_{0.05}$ for salt $\times$ urea & & 5.6 & & & 21.9 & \\
\hline
\end{tabular}


Table 6

Effect of potassium salts and addition of urea on content of potassium and calcium in dry weight of spinach leaves.

\begin{tabular}{|c|c|c|c|c|c|c|}
\hline \multirow{2}{*}{$\begin{array}{l}\text { Potassium } \\
\text { salts }\end{array}$} & \multicolumn{2}{|c|}{ Solution } & \multirow[t]{2}{*}{ Mean } & \multicolumn{2}{|c|}{ Solution } & \multirow[t]{2}{*}{ Mean } \\
\hline & $\begin{array}{c}\text { without } \\
\text { urea }\end{array}$ & $\begin{array}{l}\text { with } \\
\text { urea }\end{array}$ & & $\begin{array}{c}\text { without } \\
\text { urea }\end{array}$ & $\begin{array}{l}\text { with } \\
\text { urea }\end{array}$ & \\
\hline & \multicolumn{3}{|c|}{ potassium (\%) } & \multicolumn{3}{|c|}{ calcium $(\%)$} \\
\hline Control $\left(\mathrm{H}_{2} \mathrm{O}\right)$ & 4.22 & 4.71 & 4.46 & 1.78 & 1.56 & 1,67 \\
\hline $\mathrm{KCl}$ & 5.03 & 5.45 & 5.24 & 1.66 & 1.40 & 1,53 \\
\hline $\mathrm{KNO}_{3}$ & 5.43 & 5.60 & 5.51 & 1.50 & 1.40 & 1,45 \\
\hline $\mathrm{K}_{2} \mathrm{SO}_{4}$ & 5.38 & 5.48 & 5.43 & 1.52 & 1.40 & 1,46 \\
\hline $\mathrm{C}_{6} \mathrm{H}_{5} \mathrm{~K}_{3} \mathrm{O}_{7} \times \mathrm{H}_{2} \mathrm{O}$ & 5.09 & 5.64 & 5.36 & 1.58 & 1.28 & 1,43 \\
\hline Mean & 5.03 & 5.38 & & 1.61 & 1.41 & \\
\hline $\mathrm{LSD}_{0.05}$ for salt & \multicolumn{3}{|c|}{0.22} & \multicolumn{3}{|c|}{ n.s. } \\
\hline $\mathrm{LSD}_{0.05}$ for urea & \multicolumn{3}{|c|}{0.10} & \multicolumn{3}{|c|}{0.12} \\
\hline $\mathrm{LSD}_{0.05}$ for salt $\times$ urea & \multicolumn{3}{|c|}{0.36} & \multicolumn{3}{|c|}{ n.s. } \\
\hline
\end{tabular}

Concurrently, leaf samples were collected to determine the content of protein, vitamin $\mathrm{C}$, nitrates, chlorophyll " $\mathrm{a}+\mathrm{b}$ " and carotenoids. The content of the abovementioned compounds was determined using the following methods: protein - according to Kjeldahl; vitamin $\mathrm{C}$ according to $\mathrm{Pij}$ a n ow s ki et al. (1973); nitrates according to $\mathrm{C}$ a t a $\mathrm{ld}$ o et al. (1975); chlorophyll "a+b" according to A r n o n (1949); carotenoids according to B ritt o n (1985). Subsequently, average leaf fresh weight per plant was determined, and after drying, the content of potassium, calcium and iron was determined in leaf dry matter. The content of the abovementioned elements was determined using the atomic absorption method by means of an atomic absorption system (AAS). Prior to the analysis, fresh leaves were washed in distilled water. This paper presents average results obtained in two experiments. These data were subjected to statistical analysis using double cross-classification, determining the significance of differences by Tukey's test at the probability level $\alpha=0.05$.

\section{RESULTS AND DISCUSSION}

The results presented in Tab. 1 and 2 show that foliar feeding of all the applied potassium salts had a significantly beneficial effect on the stomatal conductance of spinach leaves and, what follows, their transpiration and photosynthesis. Feeding of $\mathrm{KNO}_{3}$, had the greatest effect on gas exchange components, $\mathrm{C}_{6} \mathrm{H}_{5} \mathrm{~K}_{3} \mathrm{O}_{7} \times \mathrm{H}_{2} \mathrm{O}$ and $\mathrm{K}_{2} \mathrm{SO}_{4}$ had a slightly smaller effect, with the smallest effect shown by $\mathrm{KCl}$. Such ef- ficiency of the used potassium salts resulted from the level of potassium accumulation in leaves. The data presented in Tab. 4 show that leaves treated with potassium nitrate contained the largest amount of potassium $(5.51 \%)$, there was a smaller amount in those fed with potassium citrate and potassium sulphate (on average $5.39 \%$ ), and the least amount in those treated with potassium chloride $(5,24 \%)$. However, compared to the control treatment, the potassium content in foliar-fed leaves was significantly higher, which confirms the opinion expressed in a paper by $\mathrm{Men}$ g e 1 (2002) as well as by A $1 \mathrm{a} \mathrm{n}$ and P a d e m (1994) that $\mathrm{K}^{+}$easily passes through the leaf epidermis. The potassium content in spinach leaves in the conditions of citrate application does not confirm the thesis of W it t wer and T a u bner (1959) that the uptake of $\mathrm{K}$ ions from potassium citrate solution is higher than that from other salts, and it is rather in agreement with the statement of A b a d i a et al. (2002) and R e ed et al. (1988) that the application of chelated forms of this nutrient does not increase its absorption compared to inorganic salt forms. Hence, the larger accumulation of potassium in spinach leaves under the influence of foliar nutrition increased the degree of stomata opening, which, as indicated by the obtained results, on the one hand, significantly increased water vapour diffusion from leaves (transpiration), and on the other hand, $\mathrm{CO}_{2}$ diffusion into the leaf interior (photosynthesis), which was also noted by F i s he r and H s i a o (1968) as well as by Hsiao and Läuchli (1986) in their studies. 
The obtained results also showed that the addition of urea to the solutions applied in each case increased stomatal conductance of leaves, thus, their transpiration and photosynthesis. It was probably associated with the beneficial effect of $\mathrm{CO}\left(\mathrm{NH}_{2}\right)_{2}$ on $\mathrm{K}$ ion accumulation in leaves (an increase by ca. 11\%), which is also confirmed by Kannan (1980) and W e in b a u m (1988).

The more efficient photosynthesis process in plants foliar-fed with potassium salts was undoubtedly a source of higher plant yields. The results contained in Tab. 2 show that all the applied potassium salts significantly increased leaf fresh weight per plant compared to the control treatment. The highest yield was produced by plants treated with potassium nitrate, which can be explained by the increased supply of potassium and nitrogen to these plants, whereas lower yields were obtained from those treated with potassium citrate, and the lowest from those fed with potassium chloride and sulphate. The addition of urea to the applied salts also increased significantly leaf yield. $\mathrm{M}$ i l e y and $\mathrm{O}$ o s t e rhu is (1994) also found, in foliar fertilization of cotton plants with $\mathrm{KNO}_{3}, \mathrm{~K}_{2} \mathrm{SO}_{4}, \mathrm{KCl}$ and $\mathrm{K}_{2} \mathrm{CO}_{3}$ salts, that potassium nitrate had the most beneficial effect on seed hairs and bolls, whereas U m a r et al. (1999) and Restre po Diaz et al. (2008) did not find any differences in the effect of $\mathrm{KCl}$ and $\mathrm{K}_{2} \mathrm{SO}_{4}$ on the yielding of peanut and olive trees.

Foliar feeding of potassium in spinach plants also affected spinach leaf quality. Plants fertilized with all the potassium salts, except for $\mathrm{K}_{2} \mathrm{SO}_{4}$, showed a higher protein content in leaves; however, significant differences were found, relative to the control treatment, in the case of $\mathrm{KNO}_{3}$ and $\mathrm{C}_{6} \mathrm{H}_{5} \mathrm{~K}_{3} \mathrm{O}_{7} \times \mathrm{H}_{2} \mathrm{O}$ (Tab. 3). Thus, these results confirm the thesis of $\mathrm{Clarks}$ on and $\mathrm{H}$ a n s e n (1980) that a large potassium concentration in the plant is necessary for efficient protein synthesis. Potassium fertilization of plants also increased the nitrate content in leaves (Tab. 3). However, a significant increase in the amount of these substances, compared to the control treatment, was found in the case of feeding of $\mathrm{KNO}_{3}$ and $\mathrm{C}_{6} \mathrm{H}_{5} \mathrm{~K}_{3} \mathrm{O}_{7} \times \mathrm{H}_{2} \mathrm{O}$ salts. The high nitrate content after the last application of $\mathrm{KNO}_{3}$, which occurred several days before the harvest, proves that the metabolization of these compounds was not completed. But it is difficult to explain why there was such an accumulation of $\mathrm{NO}_{3}$ in the case of foliar application of potassium citrate. However, the significantly higher amount of protein and nitrates in the plants additionally fed with urea seems to be obvious, since $\mathrm{CO}\left(\mathrm{NH}_{2}\right)_{2}$ was a direct source of nitrogen, used mainly for increased protein biosynthesis in leaves, but also partly for nitrate generation (Tab. 3).

Foliar application of potassium salts (except for $\mathrm{KCl}$ ) also increased significantly the content of chlorophyll and carotenoids in leaves. The leaves accumulated the largest amount of photosynthetic pigments when $\mathrm{KNO}_{3}$ was applied, and the lowest amount in the case of the application of $\mathrm{KCl}$. The addition of urea to the solutions also had a beneficial effect on the biosynthesis of both groups of pigments (Tab. 4). The beneficial effect of potassium on the synthesis of chlorophyll and carotenoids, as well as on many other important organic substances (sugars, proteins, nucleic acids), should be seen in the fact that this ion is, as reported by B u s s a k or n et al. (2003), an activator or coenzyme of numerous enzymes. Also, the fact that $\mathrm{K}^{+}$ is the main ion of osmotic solution of plants ( $\mathrm{Me} \mathrm{n} \mathrm{g}$ e 1 and A rne ke, 1982) and that its accumulation, on the one hand, increases the osmotic absorption of water by roots, and on the other hand, controls transpiration (H s i a o and Läuchli, 1986), which increases the degree of tissue hydration and supports the activity of enzymes, is not without significance.

The increased potassium content in leaves, as a result of foliar nutrition, had a significantly negative effect on vitamin $\mathrm{C}$ content. But the urea added to the solutions significantly increased its level in leaves (Tab. 5). It is difficult to express an opinion on these data due to the absence of similar studies on spinach or other leaf vegetables; in particular given the fact that a study by $\mathrm{H} \mathrm{u}$ a $\mathrm{ng}$ et al. (2000) shows that potassium increased the content of this substance in grape fruits. It can only be presumed that it was associated with the "dilution effect", since the average leaf yield in the conditions of foliar feeding of the investigated potassium salts increased by nearly $27 \%$ compared to the control treatment.

Potassium supplied by foliar application also had an effect on the mineral composition of spinach leaves. All the applied potassium salts had a positive influence on iron content; however, a significant increase in potassium content occurred in the application of potassium nitrate and citrate. The other salts as well as the addition of $\mathrm{CO}\left(\mathrm{NH}_{2}\right)_{2}$ to the solution did not affect significantly Fe content in leaves (Tab. 5). But the effect of foliar feeding of potassium salts in plants on calcium content in leaves was opposite. The increased potassium content decreased the content of $\mathrm{Ca}^{++}$, though it was not a significant effect in statistical terms. Likewise, the addition of urea to the solutions affected calcium accumulation in leaves (Tab. 6). Similar relations between potassium and calcium were also observed by Uziak and B orowski (1980/1981) in tomato leaves. They probably result from the antagonism between $\mathrm{K}^{+}$and $\mathrm{Ca}^{++}$ions, which is known in literature.

The growing medium for sowing and pricking out of plants, used in the present study, contained a sufficient amount of potassium $\left(165 \mathrm{mg} \times \mathrm{dm}^{-3}\right)$, hence, 
the content of $\mathrm{K}$ in leaves of the control plants was high $(4.46 \%)$. The use of potassium-poorer medium would probably have resulted in the achievement of even more distinct results.

\section{CONCLUSIONS}

1. Foliar feeding of potassium salts in spinach is an efficient method of supplementing the level of $\mathrm{K}^{+}$ in plants during vegetation. Plants fed with $\mathrm{KNO}_{3}$ had the highest content of potassium in leaves, and those fertilized with $\mathrm{K}_{2} \mathrm{SO}_{4}, \mathrm{C}_{6} \mathrm{H}_{5} \mathrm{~K}_{3} \mathrm{O}_{7} \times \mathrm{H}_{2} \mathrm{O}$ and $\mathrm{KCl}$ had an only slightly lower potassium content.

2. The application of potassium salt solutions resulted in more intensive gas exchange in leaves (stomatal conductance, photosynthesis, transpiration) and increased leaf yield. Potassium nitrate and citrate influenced most effectively the abovementioned processes.

3. Foliar feeding of potassium salts in spinach resulted in an increased content of protein, chlorophyll, carotenoids, nitrates and iron as well as a decreased content of vitamin $\mathrm{C}$ and calcium in leaves.

\section{REFERENCES}

Abadia J., Alvarez-Fernandez A., Morales F., S an z M., A b a di a A., 2002. Correction of iron chlorosis by foliar spray. Acta Hort. 594: 115-122.

A l a n R., P a d e m H., 1994. The effects of foliar fertilizer application on the leaf composition of spinach (Spinacea oleracea L.) Turkish J. Agric. Forestry, 18 (5): 355363.

A rnon D. J.,1949. Cooper enzymes in isolated chloroplasts: Polyphenoloxidase in Beta vulgaris. Plant Physiol. 24: $1-15$.

B ritt on G., 1985. General carotenoid methods. Methods Enzymol. 111: 113-114.

Bussakorn S. M., Daniel P. S., Michael T. T., Mark R. T., 2003. A review of potassium in grapevines with special emphasis on berry accumulation. Aust. J. Grape Wine Res. 9: 154-168.

Cataldo D. A., Harocn M., Schrader L. E., Youngs V. L., 1975. Rapid colorimetric determination of nitrate in plant tissue by nitration of salicylic acid. Commun. Soil Sci. Plant Anal. 6: 71-80.

Clarkson D. T. Hanson J. B., 1980. Mineral nutrition of higher plants. Annu. Rev. Plant Physiol. 31: 239-298.

De La Guardia M. D., Ben1loch M., 1980. Effects of potassium and gibberellic acid on stem growth of whole sunflower plants. Physiol. Plantarum, 49: 443-448.

Fish er R. A., H si a o T. C., 1968. Stomatal opening in isolated epidermal strips of Vicia faba. II. Response to $\mathrm{KCl}$ concentration and the role of potassium absorption. Plant Physiol. 43: 1953-1958.
Hsia o T. C., Läuchli A., 1986. Role of potassium in plantwater relations. Advances Plant Nutrition, 2: 281-311.

Huang X. G., Wang Q., Zhao T. C., 2000. Effect of potassium fertilizers for improving quality and production of fruit crop. J. Fruit Sci. 17 (4): 309-313.

K a n n a n S., 1980. Mechanisms of foliar uptake of plant nutrients: accomplishments and prospects. J. Plant Nutr. 2: 717-735.

Marschner H., 1995. Mineral nutrition of higher plants. London. Academic Press.

Men ge 1 K., 2002. Alternative or complementary role of foliar supply in mineral nutrition. Acta Hortic. 594: 33-48.

Mengel K., Arneke W. W., 1982. Effect of potassium on the water potential, the pressure potential, the osmotic potential and cell elongation in leaves of Phaseolus vulgaris. Physiol. Plantarum, 54: 402-408.

Miley W. N., O ost erhu is D. M., 1994. Comparison of five potassium fertilizers for foliar fertilization of cotton. Report Agric. Experiment Station. University of Arkansas Fayetteville, USA, 162: 192-195.

Orłowski M. Kołota E., 1999. Uprawa warzyw. Wyd. Brasika, Szczecin: 118.

Pijanowski E., Mrożewski, S., Horubała A., Jarczyk A., 1973. Technology of fruit and vegetable products. PWRiL W-wa: 132-134.

Reed D.W., Lyons C.G., McEachern G.R., 1988. Field evaluation of inorganic and chelated iron fertilizers as foliar sprays and soil application. J. Plant Nutr. 11: 13691378.

Restrepo Diaz H., Benlloch M., Navarro C., Fer$\mathrm{n}$ an de z-E s c obar R., 2008. Potassium fertilization of rainfeed olive orchards. Scientia Hort. 116: 399-403.

Um a r S., B a n s a 1 S. K., I m a s P., Magen H., 1999. Effect of foliar fertilization of potassium on yield, quality and nutrient uptake of groundnut. J. Plant Nutr. 22 (11): 1785-1795.

Uziak Z., B orowski E., 1980/1981. Wpływ żywienia potasowego na produkcyjność i skład chemiczny roślin. / The influence of pottassium nutrition on productivity and chemical content of plants. Ann. Univ. Mariae $\mathrm{Cu}-$ rie-Skłodowska 35/36, sect. E: 229-341.

Weinbaum S. A., 1988. Foliar nutrition of fruit trees. In: Neumann P. M. (ed), Plant growth and leaf-applied chemicals, CRC Press, Boca Raton Florida: 81-100.

Wittwer S. H., Teubner F. G., 1959. Foliar absorption of mineral nutrients. Annu. Rev. Plant Physiol. 10: 13-27.

\section{Wpływ dolistnego żywienia szpinaku solami potasu i mocznikiem na wymianę gazową, plon i jakość liści}

\section{Streszczenie}

W doświadczeniu wazonowym prowadzonym w fitotronie badano efektywność odżywiania dolistnego szpinaku (Spinacia oleracea L.) różnymi solami potasu bez i z dodatkiem $0,5 \% \mathrm{CO}\left(\mathrm{NH}_{2}\right)_{2}$. Potas zasto- 
sowano 3-krotnie w formie $1 \%$ roztworów $\mathrm{KCl}, \mathrm{KNO}_{3}$, $\mathrm{K}_{2} \mathrm{SO}_{4} \mathrm{i} \mathrm{C}_{6} \mathrm{H}_{5} \mathrm{~K}_{3} \mathrm{O}_{7} \times \mathrm{H}_{2} \mathrm{O}$ wobec wody jako kontroli. Uzyskane wyniki wykazały, że dolistne odżywianie szpinaku solami potasu jest skuteczną drogą uzupełniania poziomu $\mathrm{K}^{+} \mathrm{w}$ roślinach $\mathrm{w}$ trakcie wegetacji. Największą zawartość potasu w liściach zawierały rośliny odżywiane $\mathrm{KNO}_{3}$, a nieznacznie tylko mniejszą żywione $\mathrm{K}_{2} \mathrm{SO}_{4}, \mathrm{C}_{6} \mathrm{H}_{5} \mathrm{~K}_{3} \mathrm{O}_{7} \times \mathrm{H}_{2} \mathrm{O}$ i $\mathrm{KCl}$. Aplikacja soli potasu wpłynęła na intensywniejszy przebieg wymiany gazowej liści (przewodność szparkowa, fotosynteza, transpiracja), a w wyniku tego wzrost plonu liści. Najbardziej efektywnie na wymienione procesy oddziaływał azotan i cytrynian potasu. Traktowanie szpinaku solami potasu wpłynęło na wzrost zawartości białka, chlorofilu, karotenoidów, azotanów i żelaza, a spadek zawartości witaminy $\mathrm{C}$ i wapnia w liściach. 